\title{
Thirlwall's law at 40
}

\author{
Esteban Pérez Caldentey \\ Chief, Financing for Development Unit, Economic Development Division, Economic Commission for Latin \\ America and the Caribbean, Santiago, Chile \\ Matías Vernengo \\ Professor, Bucknell University, Lewisburg, PA, USA
}

The year 2019 marked the 40th anniversary of the publication of Anthony P. Thirlwall's classic paper titled 'The balance-of-payments constraint as an explanation of international growth rate differences' (Thirlwall 1979). This article introduced and provided empirical evidence in favor of the proposition that the long-run rate of growth of an economy compatible with balance-of-payments equilibrium can be approximated by the simple rule of the ratio of the growth of exports to the income elasticity of demand for imports.

This simple proposition known as Thirlwall's law is the dynamic analogue of the static Harrod trade multiplier result. In his book International Economics (1933), Roy Harrod had shown that the level of income equaled the level of exports divided by the propensity to import, based on the same assumptions as those of Thirlwall, that is, exports are the only component of autonomous demand, trade is balanced, and the real exchange rate (or terms of trade) does not change (Thirlwall 1997; 2018; McCombie and Thirlwall 1994). It is also similar to the model discussed by Raúl Prebisch in his American Economic Review paper (Prebisch 1959). These ideas were further developed by Nicholas Kaldor, who developed a demand-driven theory of cumulative causation, based on the supermultiplier (Kaldor 1970). Thirlwall's contribution follows in the Keynesian and Structuralist tradition of these authors.

Thirlwall's law focuses on aggregate demand as the key constraint to economic growth. According to Thirlwall's law, countries face an external constraint when

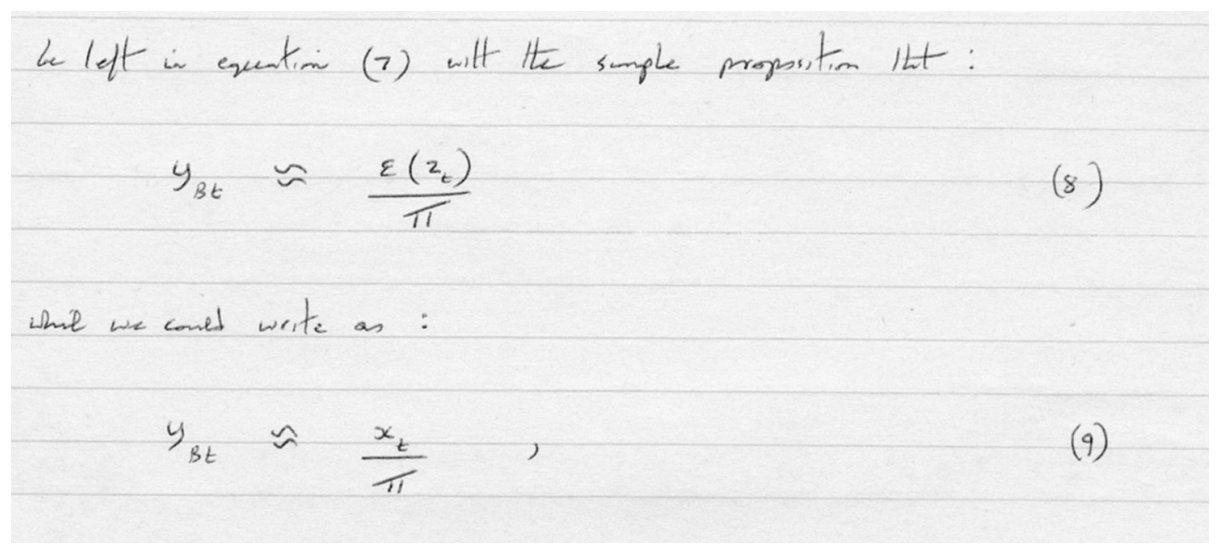

Figure 1 Thirlwall's law in the original draft 
their performance in foreign markets and the response of the financial markets to this performance restrict growth to a rate lower than internal conditions would warrant. In this sense, Thirlwall's approach is an alternative framework to mainstream theory (whether framed in terms of exogenous or endogenous growth theory) which places the focus on endowments and technology to explain growth differences between countries and for which there are no demand constraints. According to mainstream theory, which abides by Say's law, demand simply adapts to supply.

Thirlwall's law provides a theoretical underpinning for several of the arguments traditionally espoused by the heterodox followers of Keynes, which since the 1970s have been often referred to as Post-Keynesian. These include the fact that equilibrium coexists with less than full employment, that income effects prevail over substitution effects, that international payment imbalances can have negative consequences on growth, and also that, as with the case of the closed economy, money in an open economy is not neutral in the long run. In addition, Thirlwall's law can also be viewed as a guide to policy-making. Real exchange-rate variations and capital-flow movements will not guarantee an improvement in the long-run rate of the growth of an economy. The external constraint can only be eased through structural change, thereby altering the relationship between the income import and export demand elasticities.

Thirlwall's law has spurred a rich research agenda at both the theoretical and empirical levels (Thirlwall 2011). Theoretically the core model has been extended to include the different components of the current account of the balance of payments. Empirically, it has withstood the test of time and has been corroborated, with perhaps a few exceptions, for a variety of developed and developing countries under different historical contexts and different periods of time.

This special issue brings together a series of known experts and researchers to present the latest developments and debates on Thirlwall's law and to reflect and discuss how some of the latest developments in theory and those related to the evolution and workings of capitalist economies relate to the external sector and, in particular, to the concept of the balance-of-payments constraint underpinning the formulation of Thirlwall's law.

\section{REFERENCES}

Harrod, R.F. (1933), International Economics, New York: Harcourt, Brace and Company.

Kaldor, N. (1970 [1989]), 'The case for regional policies,' in F. Targetti and A.P. Thirlwall (eds), The Essential Kaldor, London: Duckworth, pp. 311-326.

McCombie, J.S.L. and A.P. Thirlwall (1994), Economic Growth and the Balance-of-Payments Constraint, New York: St Martin's Press.

Prebisch, R. (1959), 'Commercial policy in the underdeveloped countries,' American Economic Review Papers and Proceedings, 49(2), 251-273.

Thirlwall, A.P. (1979), 'The balance-of-payments constraint as an explanation of international growth rate differences,' BNL Quarterly Review, 32, 45-53.

Thirlwall, A.P. (1997), 'Reflections on the concept of balance-of-payments-constrained growth,' Journal of Post Keynesian Economics, 19(3), 377-385.

Thirlwall, A.P. (2011), 'Balance of payments constrained growth models: history and overview,' PSL Quarterly Review, 64, 307-351.

Thirlwall, A.P. (2018), 'A life in economics,' PSL Quarterly Review, 71, 9-39. 